\title{
Storcellet granulær lymfocytt-leukemi
}

\author{
Sammendrag \\ Bakgrunn. Storcellet granulær lymfo- \\ cytt-leukemi er en sjelden sykdom. \\ Kjennskap til sykdommen kan bidra til \\ målrettet og rask diagnostikk og til at \\ de behandlingstrengende pasientene \\ får effektiv behandling.
}

Metode. Vi identifiserte alle pasienter som hadde fått stilt diagnosen storcellet granulær lymfocytt-leukemi ved Seksjon for blodsykdommer, Medisinsk avdeling, Rikshospitalet i perioden 01.10. 2001-31.12. 2007. Journaldokumentasjonen ble gjennomgått retrospektivt.

Resultater. I den aktuelle perioden stilte vi diagnosen storcellet granulær lymfocytt-leukemi hos 52 pasienter, 26 kvinner og 26 menn, median alder $59(26-86)$ år. Én pasient hadde leukemi med fenotype naturlige drepeceller (NK-celler), mens leukemien hadde T-cellefenotype hos de øvrige pasientene. Drøyt en tredel av pasientene var asymptomatiske. Hos de symptomatiske pasientene lå cytopenier, først og fremst granulocytopenier, til grunn for den kliniske fenotypen. Samtidig forekomst av sykdommer med immunpatogenese var vanlig, og vi fant dessuten en høy forekomst (17\%) av klonal B-cellesykdom.

Fortolkning. Våre pasienter med storcellet granulær lymfocytt-leukemi er representative for hvordan sykdommen har vært beskrevet i litteraturen. Mistanken om denne tilstanden bør vekkes når pasienter presenterer seg med uforklarte cytopenier. Tidlig diagnose vil kunne forhindre langvarig og unødvendig utredning og sikre pasientene med behandlingsbehov en enkel og effektiv behandling.

\section{Silje Michalsen}

Elisabeth Schrumpf

Det medisinske fakultet

Universitetet i Oslo

\section{Klaus Beiske}

Anne Tierens

Patologiklinikken

Oslo universitetssykehus, Rikshospitalet

Vigdis Stenberg

Medisinsk avdeling

Ringerike sykehus

Geir E. Tjønnfjord

geir.tjonnfjord@rikshospitalet.no

Seksjon for blodsykdommer

Medisinsk avdeling

Oslo universitetssykehus, Rikshospitalet og

Fakultetsdivisjon Rikshospitalet

Universitetet i Oslo

Store granulære lymfocytter (large granular lymphocytes, LGL) utgjør 10-15\% av lymfocyttene i blod hos friske voksne (1). De fleste $(85 \%)$ av disse lymfocyttene er CD3 naturlige drepeceller (NK-celler), og de resterende er $\mathrm{CD}^{+}$cytotoksiske T-celler. Store granulære lymfocytter er mellomstore celler med rund eller oval, eksentrisk plassert kjerne med kondensert kjernekromatin uten tydelig nukleolus og med rikelig blekblått cytoplasma med noen få store azurofile granulae (fig 1).

Storcellet granulær lymfocytt-leukemi (LGL-leukemi) ble første gang beskrevet som en klonal sykdom med affeksjon av blod, milt og beinmarg i 1985 (2). Hovig og medarbeidere hadde flere år tidligere beskrevet en pasient med revmatoid artritt, splenomegali, nøytropeni og store granulære lymfocytter, og hos seks av 11 pasienter med kronisk lymfatisk leukemi av T-celletype beskrevet av Brouet og medarbeidere i 1975 hadde lymfocyttene rikelig cytoplasma med azurofile granulae $(3,4)$. Koblingen til revmatoid artritt og nøytropeni ble klarlagt et par år seinere (5).

I 1993 beskrev Loughran to typer LGLleukemi: en T-celletype som utgjorde majoriteten av tilfellene og en langt sjeldnere naturlig drepecelle-type (6). Denne todelingen er adaptert av WHO-klassifikasjonen. T-LGL-leukemi er nesten alltid en svært indolent sykdom, mens NK-LGL-leukemi ofte har en aggressiv klinisk fenotype. Aggressive varianter av T-LGL-leukemi er beskrevet. Indolent NK-LGL-leukemi forekommer også, men det er vanskelig å vise at naturlige drepeceller er klonale. Det er derfor svært utfordrende å avgjøre med sikker- het om vedvarende lymfocytose av naturlige drepeceller virkelig er uttrykk for NK-LGLleukemi. I slike tilfeller blir kliniske symptomer og infiltrasjon av naturlige drepeceller i lever, milt, beinmarg og eventuelt andre organer tillagt stor betydning.

LGL-leukemi har vært oppfattet som en svært sjelden sykdom $(7,8)$. Det angis at LGL-leukemi utgjør 2-5\% av alle T-/NKlymfoproliferative sykdommer, og frem til 2003 var bare 400 tilfeller beskrevet i litteraturen (8). Vår erfaring gjennom de siste seks årene tilsier at LGL-leukemi ikke er fullt så sjelden som anført i litteraturen og at sykdommen er underdiagnostisert. Formålet med dette arbeidet er å gjøre oppmerksom på sykdommen, vise dens kliniske fenotyper, omtale diagnostiske muligheter og utfordringer og redegjøre for behandlingsindikasjoner og behandlingsalternativer. Pasienter med LGL-leukemi kan påtreffes både $\mathrm{i}$ primærhelsetjenesten og spesialisthelsetjenesten. Kjennskap til sykdommen kan bidra til målrettet og rask diagnostikk og gjøre at effektiv behandling kan tilbys de pasientene som trenger det.

\section{Materiale og metode}

\section{Pasienter}

I studien inkluderte vi samtlige pasienter som har fått stilt diagnosen LGL-leukemi i perioden 1.10.2001-31.12.2007 og der Seksjon for blodsykdommer, Medisinsk avdeling, Rikshospitalet har vært involvert i diagnostikken. De diagnostiske kriteriene som har vært lagt til grunn er (8):

- Vedvarende ekspansjon av store granulære lymfocytter i blod og/eller infiltrasjon av store granulære lymfocytter i beinmarg eller ekstramedullært vev

- Karakteristisk immunfenotype bedømt ved væskestrømscytometri eller immuncytologi $\left(\mathrm{CD} 3{ }^{+} \mathrm{CD} 16^{+} \mathrm{CD} 56^{+/-} \mathrm{CD} 57^{+}\right.$eller $\mathrm{CD}^{-}{ }^{-} \mathrm{CD} 16^{+} \mathrm{CD} 56^{+} \mathrm{CD} 57^{+}$)

\section{Hovedbudskap}

- Storcellet granulær lymfocytt-leukemi forekommer like hyppig hos kvinner og menn

- To tredeler av pasientene har sykdomsrelaterte symptomer

- Diagnosen bør vurderes ved uforklarlige cytopenier

- Behandlingen er enkel og effektiv 
- Klonal T-/NK-cellepopulasjon ved påvisning av klonalt rearrangert T-cellereseptor (TCR) ved molekylærgenetiske metoder eller TCR-V $\beta$-restriksjon ved væskestrømscytometri og/eller påvisning av klonalt cytogenetisk avvik ved karyotyping

- Kliniske symptomer, som ses hos $70-75 \%$ av pasientene, vektlegges også i den diagnostiske prosessen, og kliniske symptomer er av særlig betydning i vurderingen av hvorvidt det foreligger behandlingsindikasjon eller ikke.

Alle de tre første kriteriene må være oppfylt for å stille diagnosen LGL-leukemi.

\section{Metode}

Vi har retrospektivt gått igjennom journalopplysninger og laboratoriedata som har vært tilgjengelig ved Rikshospitalet hos alle pasienter som har fått stilt diagnosen LGLleukemi i samarbeid med Seksjon for blodsykdommer, Medisinsk avdeling ved hjelp av sykehusets pasientadministrative system og ICD-10-kodeverket. Ikke alle pasientene har vært til klinisk undersøkelse ved Rikshospitalet. De pasientene som ikke har vært til undersøkelse ved Rikshospitalet, har ikke alltid vært undersøkt systematisk med klinisk-kjemiske og immunologiske analyser som er av interesse for å belyse fenotypiske trekk, men som ikke er nødvendig for å stille diagnosen. Vi har derfor heller ikke systematiske oppfølgingsdata på alle pasientene.

\section{Resultater}

Forekomst

I seksårsperioden som studien omfatter, har vi stilt diagnosen LGL-leukemi hos 52 pasienter, 26 kvinner og 26 menn (tab 1). Median alder ved diagnose var 59 år (26-86 år). Pasientene var ikke utelukkende fra Helse Sør-Øst, og vi kan ikke se bort ifra at pasienter $\mathrm{i}$ vårt rekrutteringsområde har fått diagnostisert LGL-leukemi i den aktuelle perioden uten vår kjennskap. Tallmaterialet gir derfor ikke grunnlag for å beregne insidens for LGL-leukemi i Norge.

\section{Immunfenotype og klonalitet}

Alle pasientene, med ett unntak, hadde LGL-leukemi av T-celletype. Hos 48 pasienter hadde leukemicellene karakteristisk immunfenotype som cytotoksiske T-celler $\left(\mathrm{CD} 2{ }^{+} \mathrm{CD} 7^{+} \mathrm{CD}^{+} \mathrm{CD}^{+} \mathrm{CD} 16^{+} \mathrm{CD} 57^{+}\right.$) (fig $2)$, men hos én pasient der leukemien hadde en aggressiv klinisk fenotype var immunfenotypen $\mathrm{CD} 2{ }^{+} \mathrm{CD} 7{ }^{+} \mathrm{CD} 3^{+} \mathrm{CD} 8{ }^{+} \mathrm{CD} 16^{+} \mathrm{CD}$ $56^{+} \mathrm{CD} 57^{-}$, og hos to pasienter var leukemicellene $\mathrm{CD}^{+} \mathrm{CD}^{-}$og for øvrig med en immunfenotype som anført ovenfor. Klonalt rearrangert T-cellereseptor ble dokumentert hos alle. Hos én pasient hadde leukemicellene naturlig drepecelle immunfenotype; $\mathrm{CD} 2^{+} \mathrm{CD} 7^{+} \mathrm{CD} 3^{-} \mathrm{CD} 8^{+} \mathrm{CD} 57^{+}$. Denne pasienten har hatt vedvarende lymfocytose $(>5$. $\left.10^{9} / 1\right)$ over flere år, og vi har dokumentert infiltrasjon av lymfocytter med den aktuelle immunfenotypen i biopsier fra beinmarg, gastrointestinalkanal og hud. Til tross for at vi ikke har kunnet vise at cellene er klonale (cytogenetisk undersøkelse), mener vi at diagnosen NK-LGL-leukemi er godt fundert hos denne pasienten.

\section{Beinmargsmorfologi}

Beinmargen var normocellulær eller hypercellulær hos alle pasientene som var undersøkt med beinmargsbiopsi. Leukemicellene viste en diffus interstitiell infiltrasjon som sjelden utgjorde mer enn $1 / 3$ av de kjerneholdige beinmargscellene (fig 3), og intrasinusoidal lokalisasjon var vanlig. Lymfoide infiltrater var også vanlig, og infiltratene besto av polyklonale B-celler omgitt av en krans av polyklonale $\mathrm{CD}^{+} \mathrm{T}$-celler.

Hos alle pasientene forelå en trilineær hematopoese med normal trombocytopoese. Erytropoesen var normal hos de fleste pasientene, men den var økt hos pasientene pasientene med erytroaplasi. Granulocytopoesen var oftest normal, men var redusert med tegn til modningsarrest hos noen pasienter med granulocytopeni.

\section{Klinisk presentasjon}

Det var mange ulike grunner til at pasientene oppsøkte helsevesenet. De aller fleste hadde symptomer og kliniske funn som gjentatte infeksjoner, autoimmune sykdommer og splenomegali eller laboratoriefunn i form av cytopenier (tab 1, tab 2). Granulocytopeni, som oftest, men ikke alltid, ledsaget av infeksjoner var vanligst (totalt 26 pasienter (50\%), 18 (35\%) med infeksjoner). Anemi var hovedproblemet hos fem pasienter $(10 \%)$, og årsaken til anemien var enten hemolyse (negativt funn ved direkte antiglobulintest (DAT)) eller erytroaplasi. Én pasient fikk stilt diagnosen T-LGL-leukemi etter utredning for trombocytopeni, men trombocytopeni ble påvist hos i alt 11 pasienter. Ingen av pasientene hadde alvorlig med hemolytisk anemi og sterkt redusert hos

Tabell 1 Karakteristika hos 52 pasienter med LGL-leukemi

\begin{tabular}{|c|c|}
\hline Antall & 52 \\
\hline Kvinner & 26 \\
\hline Menn & 26 \\
\hline \multicolumn{2}{|l|}{ Hematologi } \\
\hline \multicolumn{2}{|l|}{ Nøytrofile granulocytter $(n=41)$} \\
\hline Median (spredning) $\cdot 10^{9} / \mathrm{l}$ & $\begin{array}{c}1,5 \\
(0-11,4)\end{array}$ \\
\hline$<1,0 \cdot 10^{9} / l$ & 18 \\
\hline$<0,5 \cdot 10^{9} / l$ & 15 \\
\hline \multicolumn{2}{|l|}{ Trombocytter ( $n=43$ ) } \\
\hline Median (spredning) $\times 10^{9} / \mathrm{l}$ & $\begin{array}{c}198 \\
(42-456)\end{array}$ \\
\hline$<150 \cdot 10^{9} / l$ & 8 \\
\hline$<100 \cdot 10^{9} / l$ & 3 \\
\hline \multicolumn{2}{|l|}{ Hemoglobin ( $n=42$ ) } \\
\hline Median (spredning) g/100 ml & $\begin{array}{c}12,8 \\
(6,4-16,8)\end{array}$ \\
\hline$<11 \mathrm{~g} / 100 \mathrm{ml}$ & 9 \\
\hline$<10 \mathrm{~g} / 100 \mathrm{ml}$ & 4 \\
\hline \multicolumn{2}{|l|}{ Lymfocytter ( $\mathrm{n}=37$ ) } \\
\hline Median (spredning) $\times 10^{9} / \mathrm{l}$ & $\begin{array}{c}2,6 \\
(0,6-247)\end{array}$ \\
\hline \multicolumn{2}{|l|}{ Organomegali } \\
\hline Splenomegali & 10 \\
\hline Hepatomegali & 4 \\
\hline Splenektomi & 8 \\
\hline \multicolumn{2}{|l|}{ Annen sykdom } \\
\hline Revmatoid artritt & 11 \\
\hline Systemisk lupus erythematosus & 1 \\
\hline Myositt & 1 \\
\hline Polynevropati & 2 \\
\hline \multicolumn{2}{|c|}{ Annen klonal lymfoproliferativ sykdom } \\
\hline Monoklonal gammopati & 8 \\
\hline Lymfom & 1 \\
\hline \multicolumn{2}{|l|}{ Annen malign sykdom } \\
\hline Cancer & 7 \\
\hline Myelodysplastisk syndrom & 1 \\
\hline
\end{tabular}

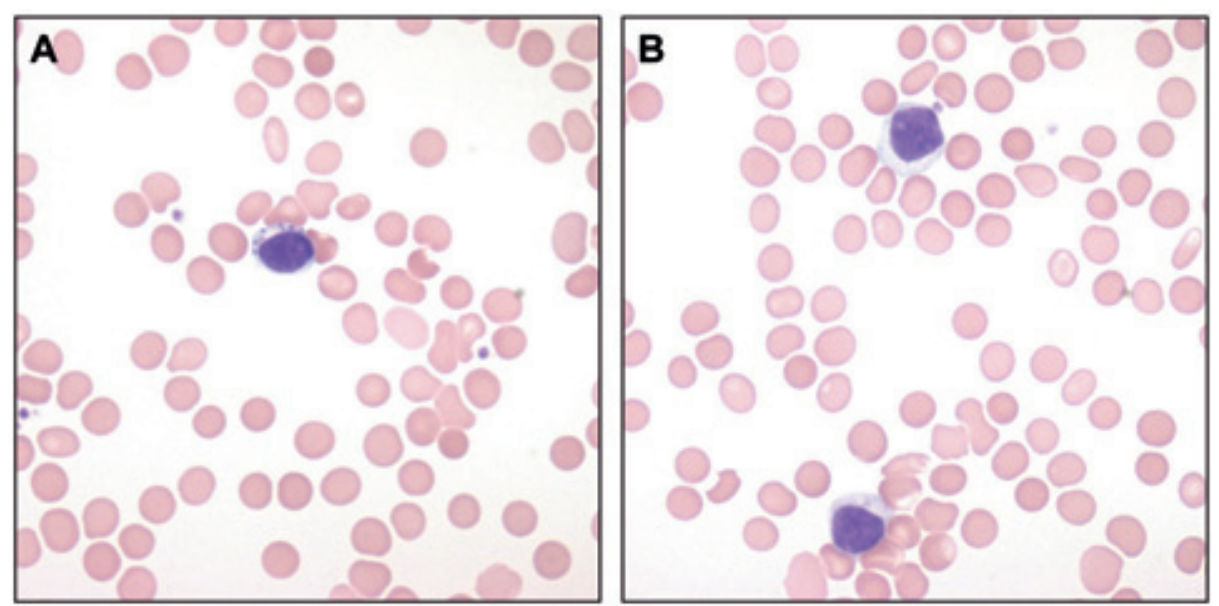

Figur 1 To utsnitt fra blodutstryk fra en pasient med storcellet granulær lymfocytt-leukemi. a) En stor lymfocytt med blekblått cytoplasma og 7-8 store og kraftige azurofile granulae. b) To store lymfocytter med ganske rikelig blekblått cytoplasma med diskrete azurofile granulae 

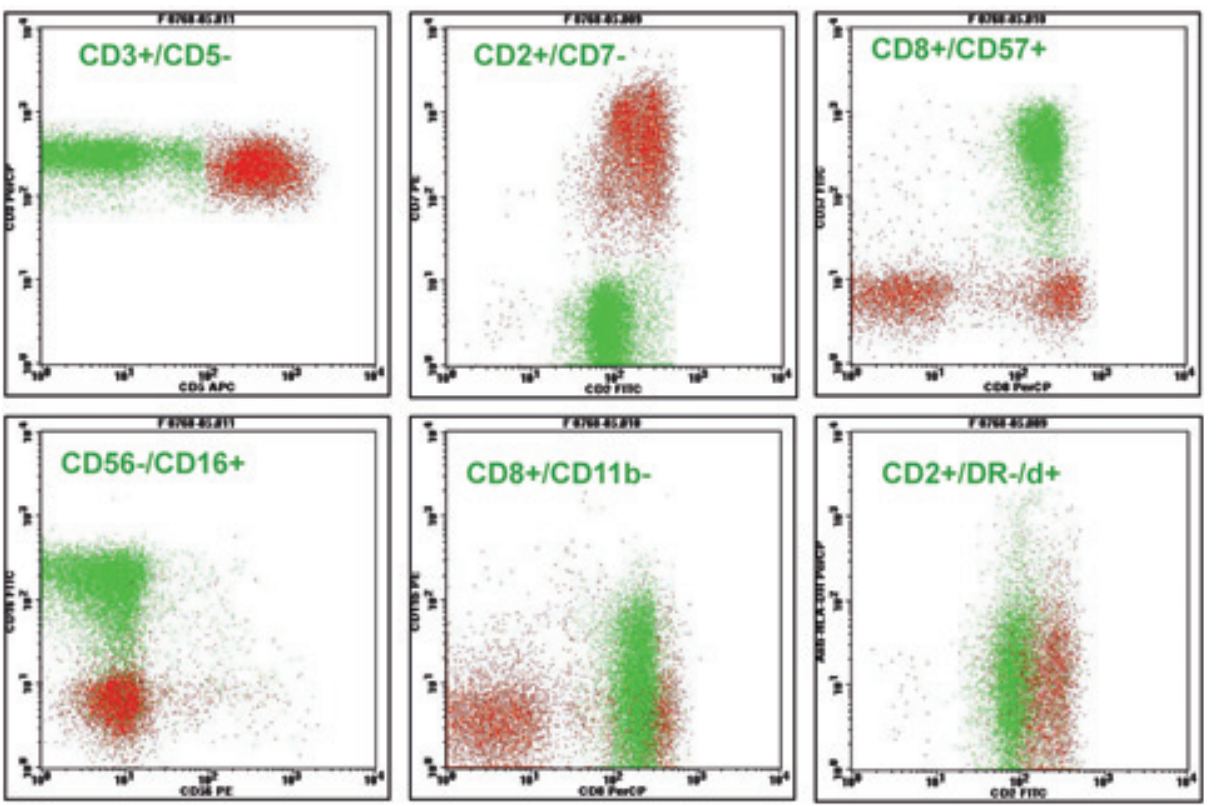

Figur 2 Væskestrømscytometrisk undersøkelse av lymfocytter i blod hos pasient med storcellet granulær lymfocytt-leukemi. Den klonale T-cellepopulasjonen gjenfinnes som den grønne populasjonen i cyto grammene og den har følgende immunfenotype: $C D 2^{+} C D 3^{+} C D 8^{+} C D 16+C D 57^{+}$. Manglende ekspresjon av CD5 og CD7 på de leukemiske T-cellene er vanlig ved storcellet granulær lymfocytt-leukemi av T-celletype

trombocytopeni med blødningsmanifestasjoner.

Hos åtte pasienter $(15 \%)$ var det utredning av moderat lymfocytose som førte til at diagnosen ble stilt, mens én pasient presenterte seg med allmennsymptomer, splenomegali, diskret lymfeknutesvulst og uttalt lymfocytose. 19 pasienter (37\%) var asymptomatiske ved diagnosetidspunktet, i alle fall hva gjelder symptomer som det er rime-
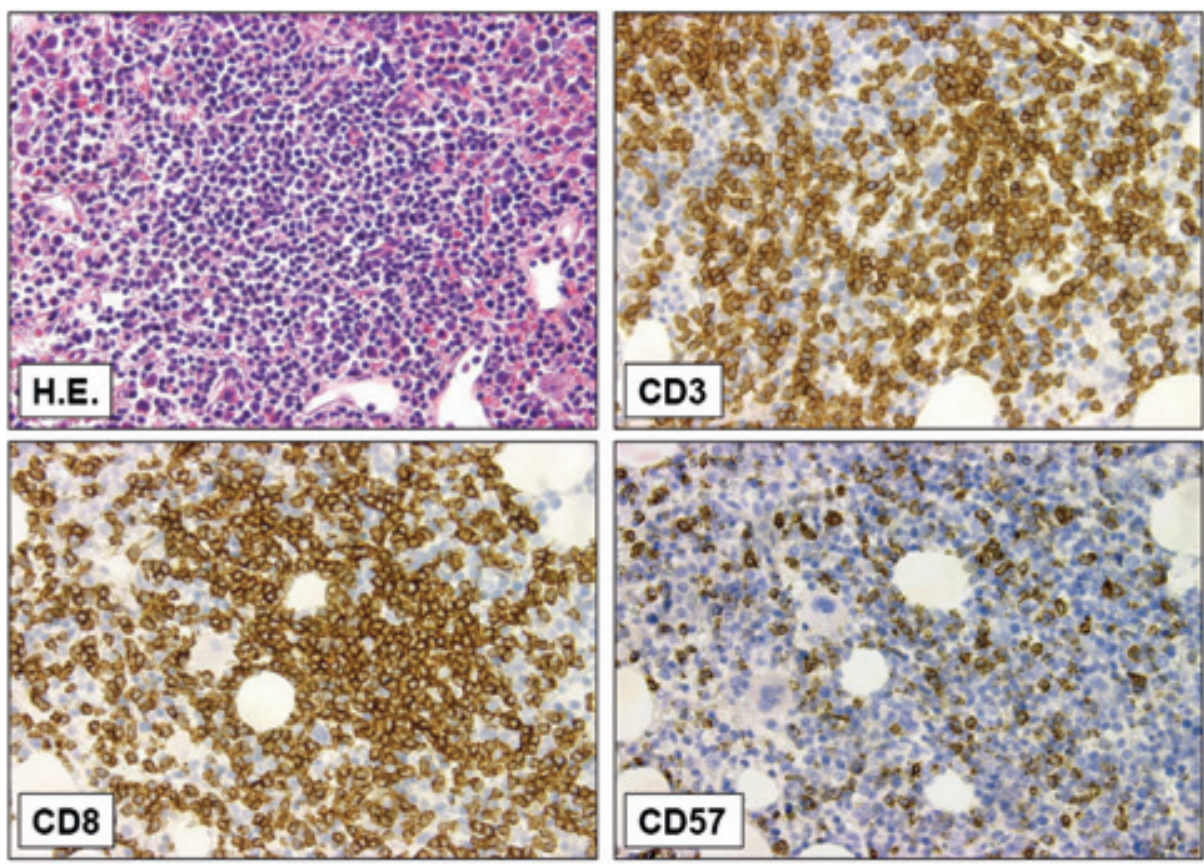

Figur 3 Beinmargsbiopsi fra pasient med storcellet granulær lymfocytt-leukemi med omfattende beinmargsaffeksjon. Snitt farget med hematoksylin og eosin (H.E.) viser en diffus infiltrasjon av små og middels store lymfoide celler. De aller fleste lymfocyttene er CD3+ og CD8+, og mange uttrykker også NK-celleantigenet CD57 ( $\times 40)$ gali. Fire pasienter ( $8 \%$ ) hadde hepatomegali, og to pasienter (4\%) hadde en diskret, men generell lymfeknutesvulst.

Mange pasienter hadde andre sykdommer med immunpatogenese (tab 1). Revmatoid artritt var den hyppigste årsaken til komorbiditet $(21 \%)$. Ti av 29 undersøkte pasienter testet positivt for revmatoid faktor, og tre av 19 undersøkte pasienter hadde positive funn på direkte antiglobulintest.

Tegn til annen klonal lymfoproliferativ sykdom ble funnet hos ni pasienter, som oftest monoklonal gammopati (tab 1). Hos pasientene med monoklonal gammopati kunne vi ikke stille noen sikker malignitetsdiagnose, og de må rubriseres som monoklonale gammopatier uten sikker klinisk betydning (MGUS). Resultatet av proteinelektroforese av serum var bare kjent hos 18 pasienter. Åtte pasienter (15\%) fikk påvist malignitet i ikke-lymfoid vev; sju cancer og en myelodysplasi. Malignitetsdiagnosen ble stilt før eller under oppfølging av LGL-leukemien.

\section{Behandling}

Indikasjonen for å starte behandling var symptomgivende cytopeni (tab 3), med unntak av pasienten med NK-LGL-leukemi der allmennsymptomer og hudaffeksjon var grunnlaget for behandling. Pasientene har fått behandling med ciklosporin eller metotreksat. Ved ciklosporinbehandlingen var siktemålet å oppnå medikamentfastende konsentrasjon av ciklosporin i nivå 100-150 $\mu \mathrm{g} / \mathrm{l}$. Ved effekt ble ciklosporindosen forsøkt redusert til minste effektive dose for å redusere risikoen for nefrotoksisitet ved langtidsbehandling. Osuji og medarbeidere har omhandlet responskriteriene for denne type behandling (9). Metotreksat ble gitt peroralt én gang ukentlig $\left(10 \mathrm{mg} / \mathrm{m}^{2}\right)$, og dosen ble justert på bakgrunn av effekt og/eller eventuelle bivirkninger. Ciklosporin ble kombinert med granulocyttkolonistimulerende faktor (G-CSF) hos noen få pasienter som ikke hadde ønsket effekt av monoterapi (tab 3). Kombinasjonsbehandlingen viste seg effektiv, og vi kunne seponere G-CSF og fortsette med ciklosporin alene med tilfredsstillende effekt.

Hos to pasienter med erytroaplasi ble erytropoietin benyttet i tillegg til ciklosporin. En av pasientene ble transfusjonsuavhengig etter kombinasjonsbehandling, mens den andre pasienten først ble transfusjonsuavhengig etter monoterapeutisk behandling med pentostatin $\left(4 \mathrm{mg} / \mathrm{m}^{2}\right.$ intravenøst hver 2. uke). Ciklosporin ble seponert pga. nefrotoksisitet hos to pasienter og erstattet med metotreksat med vedvarende effekt. Én pasient fikk granulocyttkolonistimulerende faktor som monoterapi, med god effekt. Grunnen var at pasientens granulocytopeni lenge ble oppfattet som kronisk idiopatisk nøytropeni.

Pasienten som hadde et aggressivt sykdomsbilde med klare kliniske likhetstrekk 
med T-prolymfocyttleukemi (T-PLL), ble initialt behandlet med alemtuzumab etterfulgt av allogen stamcelletransplantasjon med HLAidentisk familiegiver i første remisjon.

\section{Diskusjon}

Over en seksårsperiode har vi diagnostisert LGL-leukemi hos 52 pasienter. Dette er overraskende mange pasienter sammenholdt med at litteraturen angir at LGL-leukemi kun utgjør $2-5 \%$ av alle T-/NK-lymfoproliferative sykdommer (8). Vi mener sykdommen sannsynligvis er underdiagnostisert. Prognosen er god (median overlevelse 14,5 år), også hos de pasientene som har alvorlig granulocytopeni dersom cytopenien heves ved behandling (9), og overlevelsen skiller seg sannsynligvis ikke særlig fra overlevelsen $i$ en alderstilpasset kontrollgruppe. Dette innebærer at prevalensen av sykdommen ikke er helt ubetydelig.

I vårt materiale var det like mange menn som kvinner, og median alder ved diagnose var 59 år. De kliniske symptomene hos våre pasienter var nesten utelukkende relatert til cytopenier, og nøytropeni med gjentatte infeksjoner var den vanligste kliniske fenotypen. Vi fant også en høy prevalens av andre sykdommer med immunpatogenese hos våre pasienter. Vårt materiale samsvarer i så måte svært godt med litteraturen (6-9).

Monoklonal gammopati av usikker betydning (MGUS) ble påvist hos åtte pasienter, dvs. $44 \%$ av de pasientene der resultatet av proteinelektroforese var kjent for oss og $15 \%$ av hele materialet. Prevalensen av MGUS i en uselektert kaukasisk populasjon med samme median alder er ca. 3\% (10). Viny og medarbeidere har nylig rapportert tilsvarende høy forekomst av klonal B-cellesykdom ved LGL-leukemi (11).

Cytopenier hos voksne pasienter som ikke har noen åpenbar forklaring, bør vekke mistanke om LGL-leukemi. Noen har reist spørsmål ved berettigelsen av denne diagnostiske entiteten, men etter vår mening er det nyttig å stille diagnosen selv om vi er enige $i$ at bruken av betegnelsen leukemi kan skape utfordringer når det gjelder informasjon til pasientene. For det første kan diagnosen sette punktum for en ofte langvarig utredning. For det andre kan diagnosen føre til at effektiv behandling iverksettes dersom det anses indisert å korrigere cytopenien(e).

Medikamentell behandling, enten i form av ciklosporin eller metotreksat, er ikke cytoreduktiv, men immunmodulerende. Riktignok kan man se en reduksjon av antallet tumorceller i blod og beinmarg ved behandling med metotreksat, men dette antas ikke å være vesentlig for effekten av behandlingen. Vi har ikke fullstendige opplysninger om behandlingsresultatene i dette pasientmaterialet, men behandlingsresultatene for åtte av pasientene har vært publisert tidligere som del av en større internasjonal multisenterstudie (9). Ciklosporin og metotreksat anses som likeverdige behandlingsalterna-

Tabell 2 Hematologiske parametere (median, spredning) hos pasienter med LGL-leukemi gruppert etter klinisk presentasjonsform

\begin{tabular}{lcccc} 
& $\begin{array}{c}\text { Nøytropeni } \\
(\mathrm{n}=26)\end{array}$ & $\begin{array}{c}\text { Anemi } \\
(\mathrm{n}=5)\end{array}$ & $\begin{array}{c}\text { Trombocytopeni } \\
(\mathrm{n}=1)\end{array}$ & $\begin{array}{c}\text { Lymfocytose } \\
(\mathrm{n}=9)\end{array}$ \\
\hline Hemoglobin $(\mathrm{g} / 100 \mathrm{ml})$ & $12,2(7,3-17)$ & $8,9(6,4-11,3)$ & 12,3 & $14,3(12,1-16,8)$ \\
\hline Leukocytter $\left(\cdot 10^{9} / \mathrm{l}\right)$ & $2,7(0,8-18,6)$ & $8,95(2,7-13,5)$ & 4,06 & $12,3(8,7-453)$ \\
\hline Granulocytter $\left(\cdot 10^{9} / \mathrm{l}\right)$ & $0,2(0-3,8)$ & $1,5(0,86-2,0)$ & 2,07 & $3,2(<1-11,41)$ \\
\hline Lymfocytter $\left(\cdot 10^{9} / \mathrm{l}\right)$ & $1,46(0,64-13,4)$ & $6,1(1,42-10,78)$ & 1,47 & $8,8(4,9-247)$ \\
\hline Trombocytter $\left(\cdot 10^{9} / l\right)$ & $191(99-414)$ & $315(158-456)$ & 68 & $198(42-333)$
\end{tabular}

Tabell 3 Behandling initiert ved Rikshospitalet ved LGL-leukemi

\begin{tabular}{|c|c|c|c|}
\hline Indikasjon & Antall pasienter & $\begin{array}{c}\text { Antall } \\
\text { som responderte }\end{array}$ & Ikke vurderbare \\
\hline \multicolumn{4}{|l|}{ Granulocytopeni } \\
\hline Ciklosporin & 9 & 8 & 1 \\
\hline Metotreksat & 4 & 3 & 1 \\
\hline Ciklosporin m/G-CSF & 2 & 2 & \\
\hline \multicolumn{4}{|l|}{ Anemi } \\
\hline Ciklosporin & 4 & 3 & 1 \\
\hline Metotreksat & 2 & 1 & \\
\hline Pentostatin & 1 & 1 & \\
\hline Ciklosporin m/erytropoietin & 2 & 1 & \\
\hline Trombocytopeni & & & \\
\hline
\end{tabular}

tiver, og respons kan forventes hos $80 \%$ av pasientene (9). Effekt ses innen tre måneder etter oppstart. Manglende effekt av ciklosporin tilsier ikke nødvendigvis manglende effekt av metotreksat og vice versa (9). Hos et lite mindretall av pasientene kan det være aktuelt å kombinere den immunmodulerende behandlingen med granulocyttkolonistimulerende faktor eller erytropoietin. Effekten bibeholdes som regel med vedvarende immunmodulerende behandling selv om cytokinbehandlingen avvikles etter oppnådd effekt (9). Den immunmodulerende behandlingen kan vanligvis ikke avvikles uten tap av effekt selv om remisjonen kan vedvare $\mathrm{i}$ år etter behandlingsslutt hos et fåtall av pasientene (9). Kraftig cytoreduktiv behandling vil ofte vise seg ineffektiv (12). Det er ingen publiserte studier som gir anbefalinger om behandling hos de få pasientene der LGL-leukemien har en aggressiv klinisk fenotype. Presentasjonen hos en av våre pasienter hadde svært mye til felles med T-prolymfocytt leukemi, og vi valgte derfor en behandlingsstrategi som ved denne tilstanden (13).

En drøy tredel av pasientene var asymptomatiske, og spesielt hos disse kan man naturligvis stille spørsmål ved berettigelsen av å benytte betegnelsen LGL-leukemi. Det er mulig at betegnelsen monoklonal T-lymfocytose (MTL), som så langt ikke har vært lansert internasjonalt, ville være vel så passende, og ikke minst lettere å forholde seg til for pasientene. Monoklonal B-lymfocytose (MBL) har vært lansert som betegnelse for de tilfeller der det foreligger en klonal ekspansjon av modne B-lymfocytter, men der de diagnostiske kravene for kronisk lymfatisk leukemi eller annen kronisk lymfoproliferativ sykdom ikke er tilfredsstilt (14). LGLleukemi av den indolente typen viser sjelden eller aldri noen vesentlig progresjon som tumorsykdom betraktet, og transformasjon til en aggressiv lymfoproliferativ sykdom er sjeldent (15). Det er derfor argumenter for å benytte betegnelsen monoklonal T-lymfocytose (MTL) i stedet for T-LGL-leukemi, spesielt $i$ de tilfellene hvor pasientene er uten kliniske sykdomsmanifestasjoner.

Silje Michalsen og Elisabeth Schrumpf har levert likeverdige bidrag til dette manuskriptet.

Oppgitte interessekonflikter: Vigdis Stenberg har mottatt økonomisk støtte til kongresser og faglige møter/kurs fra firma som markedsfører medikamenter til behandling av maligne blodsykdommer. Øvrige forfattere har ingen oppgitte interessekonflikter.

\section{Litteratur}

1. Lamy T, Loughran TP. Large granular lymphocyte leukemia. Cancer Control 1998; 5: 25-33.

2. Loughran TP jr, Kadin ME, Starkebaum G et al. Leukemia of large granular lymphocytes: association with clonal abnormalities and autoimmune neutropenia, thrombocytopenia and haemolytic anmeia. Ann Intern Med 1985; 102: 169-75. 
3. Hovig T, Jeremic M, Stavem P. A new type of inclusion bodies in lymphocytes. Scand J Haematol 1968; 5: 81-96.

4. Brouet JC, Sasportes M, Flandrin G et al. Chronic lymphocytic leukaemia of T-cell origin. Immunological and clinical evaluation in eleven patients. Lancet 1975; 2: 890-3.

5. McKenna RW, Parkin J, Kersey JH et al. Chronic lymphoproliferative disorder with unusual clinical, morphological, ultrastructural and membrane surface marker characteristics. Am J Med 1977; 62: $588-96$.

6. Loughran TP jr. Clonal diseases of large granular lymphocytes. Blood 1993; 82: 1-14.

7. Berentsen S, Bruserud $\emptyset$, Ulvestad E. Storcellet granulær lymfocyttleukemi. Tidsskr Nor Lægeforen 1998; 118: 1045-8.

8. Sokol L, Loughran TP jr. Large granular lymphocyte leukemia. Oncologist 2006; 11: 263-73.

9. Osuji N, Matutes E, Tjønnfjord G et al. T-cell large granular lymphocyte leukemia: A report on the treatment of 29 patients and a review of the literature. Cancer 2006; 107: 570-8.

10. Kyle RA, Therneau TM, Rajkumar SV et al. Prevalence of monoclonal gammopathy of undetermined significance. N Engl J Med 2006; 354: 1362-9.
11. Viny AD, Lichtin A, Pohlman B et al. Chronic B-cell dyscrasias are an important clinical feature of $\mathrm{T}$ LGL leukemia. Leuk Lymphoma 2008; 49: 932-8.

12. Osuji N, Matutes E, Wotherspoon A et al. Lessons from a case of T-cell large granular lymphocytic leukaemia suggesting that immunmodulatory therapy is more effective than intensive treatment. Leuk Res 2005; 29: 225-8.

13. Dearden $C E$, Matutes $E$, Cazin B et al. High remission rate in T-cell prolymphocytic leukemia with CAMPATH-1H. Blood 2001; 98: 1721-6.

14. Marti GE, Rawstron AC, Ghia P et al. Diagnostic criteria for monoclonal B-cell lymphocytosis. $\mathrm{Br}$ J Haematol 2005: 130: 325-32.

15. Matutes E, Wotherspoon AC, Parker NE et al. Transformation of T-cell large granular lymphocyte leukaemia into a high-grade large T-cell lymphoma. Br J Haematol 2001; 115: 801-6.

Manuskriptet ble mottatt 27.4. 2008 og godkjent 27.3. 2009. Medisinsk redaktør Åslaug Helland. 